\title{
Surfaces
}

\section{Jacques Derrida's "Des humanités et de la discipline philosophique"/"Of the Humanities and Philosophical Disciplines"

\author{
Roundtable Discussion
}

\section{Hazard Adams, Ernst Behler, Hendrik Birus, Jacques Derrida, Wolfgang Iser, Murray Krieger, Hillis Miller, Ludwig Pfeiffer, Bill Readings, Ching-hsien Wang et Pauline Yu}

\section{Volume 6, 1996}

DISCUSSIONS DU PREMIER CONGRÈS INTERNATIONAL SUR LE

DISCOURS HUMANISTE

DISCUSSIONS FROM THE FIRST INTERNATIONAL CONFERENCE ON HUMANISTIC DISCOURSE

URI : https://id.erudit.org/iderudit/1064845ar

DOI : https://doi.org/10.7202/1064845ar

Aller au sommaire du numéro

Éditeur(s)

Les Presses de l’Université de Montréal

ISSN

1188-2492 (imprimé)

1200-5320 (numérique)

Découvrir la revue

Citer ce document

Adams, H., Behler, E., Birus, H., Derrida, J., Iser, W., Krieger, M., Miller, H., Pfeiffer, L., Readings, B., Wang, C.-h. \& Yu, P. (1996). Jacques Derrida's "Des humanités et de la discipline philosophique"/"Of the Humanities and Philosophical Disciplines": Roundtable Discussion. Surfaces, 6. https://doi.org/10.7202/1064845ar

\section{Résumé de l'article}

Ces discussions autour du texte de Jacques Derrida, « Des humanités et de la discipline philosophique » ("Of the Humanities and Philosophical Disciplines »), ont eu lieu en avril 1994, dans le cadre du premier Congrès sur le Discours Humaniste. Les communications de cette première réunion du Congrès ont été publiées dans le volume 4 de Surfaces (1994).
Copyright ( $)$ Hazard Adams, Ernst Behler, Hendrik Birus, Jacques Derrida, Wolfgang Iser, Murray Krieger, Hillis Miller, Ludwig Pfeiffer, Bill Readings, Ching-hsien Wang et Pauline Yu, 1996
Ce document est protégé par la loi sur le droit d'auteur. L’utilisation des services d'Érudit (y compris la reproduction) est assujettie à sa politique d'utilisation que vous pouvez consulter en ligne.

https://apropos.erudit.org/fr/usagers/politique-dutilisation/ 
Jacques Derrida's "Des humanités et de la discipline philosophique"/"Of the Humanities and

Philosophical Disciplines"

\title{
Roundtable Discussion
}

\author{
Hazard Adams \\ Ernst Behler \\ Hendrick Birus \\ Jacques Derrida \\ Wolfgang Iser \\ Murray Krieger \\ Hillis Miller \\ Ludwig Pfeiffer \\ Bill Readings \\ Ching-hsien Wang \\ Pauline $\mathrm{Yu}$
}

Surfaces Vol. VI.108 (v.1.0A - 16/08/1996) - ISSN:

1188-2492

Copyright for texts published in Surfaces remains the property of authors. However, any further publication should be accompanied by an acknowledgement of Surfaces as the place of initial publication.

\begin{abstract}
This roundtable discussion of "Des humanités et de la discipline philosophique" ("Of the Humanities and Philosophical Disciplines"), Jacques Derrida's contribution to the first International Conference for Humanistic Discourses, was held in April, 1994. The papers
\end{abstract}


of this first meeting of the ICHD have been published in volume 4 of Surfaces (1994).

\section{RÉSUMÉ}

Ces discussions autour du texte de Jacques Derrida, "Des humanités et de la discipline philosophique" ("Of the Humanities and Philosophical Disciplines"), ont eu lieu en avril 1994, dans le cadre du premier Congrès sur le Discours Humaniste. Les communications de cette première réunion du Congrès ont été publiées dans le volume 4 de Surfaces (1994).

Behler : I'm pleased to open the last session, and to ask the last presenter to speak to us. This, is of course, not because it is the last session and the last presenter, but because it is Jacques, who has had an extraordinary presence at our conference, not only through his remarks and observations to individual papers, but also an intellectual presence in many of the papers presented here.

Derrida : Thank you, Ernst. I won't summarize the paper. I'm not good at that, and then I think it's better for me to go around the paper and justify it, if possible. It was under another form initially when delivered at the UNESCO in Paris. As you probably know, there is the problem of philosophy being a part of this institution, and its history from the beginning of the UNESCO. So why did I choose to adapt, adjust it here? Three points, and I'll try and be brief. First, should I apologize for having left my paper in French? I should, of course. But on the other hand, I think that seeing the problem of language, and especially of the dominant and excluded languages is already alluded to by Kant and in the paper, in different ways. I wanted to effectively, performatively, let's say, ask the question, why read my text in French? Now, if I do so, it's not a matter of, let's say, antagonism or anti-Americanism, or some well known opposition to the current linguistical, political hegemony of English, American English. It's because, on the one hand, I think that, our conference, our project, bears witness to that the Anglo-American is and will remain our medium in our discussions. Why is it so? How can we account for that? Usually, although it's a well known phenomenon 
that today Anglo-American is the universal language, the only universal language effectively, the reasons why it is so are not clear, not simply a question of political or economic power. We should account for that, and have responsible answers to this current hegemony. I say this all the more in the spirit of, let's say, friendship to AngloAmerican language, but I think that this hegemony is even a problem for the Anglo-American speakers. Each time I have to enter this debate (we all have to do that), I insist on the fact that the threat, if there is a threat, is not only a threat to other languages. It's also a threat to English, to some experience of English.

Second point. I thought I should put philosophy on the table because so far it's literature which has been privileged. So my questions about philosophy in this context are seven. First, as a discipline, as a discipline. Can we say that philosophy as a discipline is part of the humanities, or not? Is philosophy part of a culture, of what one calls "culture"? As you know, there is in philosophy, especially in twentieth century philosophy, an objection to the inclusion of it in the space of culture. Heidegger, for instance, would say, well, philosophy is not a cultural phenomenon. When we speak of culture, we have immediately to do with multiple differences in history, in the history of in the arts, and so on and so forth, whereas philosophy is like science, in that the project of philosophy is, as a project, universal. To that extent, philosophy doesn't belong to a culture. I don't share this view. There are cultural aspects of philosophy, but philosophy is not a cultural phenomenon. Then, always considering philosophy as a discipline, we all know here (all of us have been privy to this fact) that philosophy, especially German philosophy in the late nineteenth century, has played a major role in the construction of the model of the university. So in order to refer to this philosophical structure of the model of the university, in the same way, I wanted to emphasize the fact that the very concept of this international institution is philosophical through and through. That is, the concept, the charter, the constitution of the UNESCO is grounded on philosophical concepts, philosophical European concepts, and that's why it's a philosophical institution. So I think we have to interpret, to analyze the history of the academic models in Europe, in the States, in the world, from a philosophical point of view. Then as to philosophy as a discipline. As we know, the place and the extension given philosophy in different cultures, and even in the West, in different nations, different systems of education, are different, but they have something in common today. This is something philosophy has in 
common with all the humanities: the reduction of the space, reduction of money, reduction of the power, because philosophy supposed to be useless in our industrial societies, and it's a matter of a political struggle. In my own country, we constantly are fighting and struggling against the reduction of the philosophical space in the high schools (in France, philosophy starts in the high schools), and of course in the universities. Then my second point, philosophy not as a discipline, but philosophy as the implied or supposed authority in what we referred to yesterday or the day before yesterday as Begriffsgeschichte. Of course, it's not necessarily a philosophical project, but we know that implicitly the history of concepts is philosophically structured, and the authority for the history of the concepts (especially the concepts we are dealing with - - culture, translation, is in principle philosophical. A third sub-point: philosophy is supposed to be the place from which one defines (and this is not only a matter of Begriffsgeschichte), one defines the concepts of man, humanity, what is man, what are the transformations of the concept of man today, what is humanism - all these questions are philosophical through and through, and we have to, even if we disagree with philosophical claims or philosophical interpretations about this, we have to face this philosophical claim about these concepts. And this is perhaps the most important point to me within the second point: the relationship between philosophy and natural languages, European languages. And I try in my paper to avoid the opposition between two symmetrical temptations, one being to say rapidly that of course philosophy is something universal. Today it's a wellknown phenomenon - there is a Chinese philosophy, a Japanese philosophy and so on and so forth. That's a contention I would resist. I think there is something specifically European, specifically Greek in philosophy to simply say that philosophy is something universal. Now saying this, I think that every kind of thinking, thought, is philosophical. I will distinguish philosophy and Denken, thinking. Philosophy is a way of thinking. It's not science. It's not thinking in general. So when I say, well, philosophy has some privileged relationship with Europe, I don't say this European-centrically but to take seriously history. That's one temptation, to say philosophy is universal. The other temptation would be the one I just sketched: well, philosophy has only one origin, a single pure origin that is its foundation, its institution, through a number of grounding concepts which are linked to Greek language, and we have to keep this in memory and go constantly back to Greece and back to this Greek origin, European, through anamnesis, through memory, to what philosophy is. This is a 
symmetrical temptation which I would like to avoid. So what I propose is another model: that is, while keeping in memory this European, Greek origin of philosophy, and the European history of philosophy, take into account that there are events, philosophical events, which cannot be reduced to this single origin, and which mean that the origin itself was not simple, that the phenomenon of hybridization, of graft, or translation, was there from the beginning, so we have to analyze the different philosophical events today, in Europe and outside of Europe. This avoids at the same time Eurocentrism and simple-minded anti-Eurocentrism. That would be the last sub-point in the second point.

And the last, the very last point, would have to do with philosophy and literature. Why then choose this among other things? There are many reasons for this choice, but I won't summarize them now. I'm thinking of the reference that Kant makes to the Roman, and the way he tried to distinguish between philosophy and the novel.

And we have here a classical philosophical gesture in the philosophical exclusion of literature, philosophy becoming what it is or what it should be by simply avoiding literature. That's why I've chosen this text. The way (that's what I say, page nine) the way Kant tries to avoid literature, or novel, Roman, is precisely the reference to the Greek history, when he says (page eight), when he says, "In order to contradict this Romanesque hypothesis and to think the human history, beyond the novel, as a system and not simply as an agregat sans plan, a programless aggregation, or composition, then we have to follow the living thread of Greek history, the only one," he says, "which (transmette) transfers or translates all the other histories which have been prior or contemporaneous..." So it's again through reference to the Greek origin that Kant claims that indeed one can, of course, purify philosophy from literature. And I think this might be one of the places for discussion here.

Behler : Well, my task is now to respond to you, and I will do this by outlining a number of topics we might like to discuss and to which you might like to respond, but I will also refer back to your paper - not by way of summarizing it, just by picking something here and there. And what I consider most important in the first place (it would be my first point) in your paper and in your presentation is that it puts philosophy onto the agenda for a group that is usually inclined to deny the difference between philosophy and literature. Of course, what you articulate is a special type of philosophy. It is not the systematic type of philosophy as Kant develops it 
in his Critiques. It is more philosophy in the sense of his popular writings, namely, the writings on faculties, on history, that is a type of philosophy that he himself defines as "Weltweisheit," "world wisdom." This philosophy speculates about things that, according to the Critique, are forbidden to speculate about. You cannot speculate about the end of history or the further course of history, because that's a transcendent use of reason. In these texts, Kant does it nevertheless, although the first Critique forbids it.

And how does he do it? (And this is perhaps a second point). I want to say that the reason literature does not show up in this text is that literature is not in his purview. He is not concerned with literature. When he talks about education (and education is an essential matter in these essays), it is philosophy that does education. You still have this idea in Hegel, in Hegel's Encyclopedia: education is done by philosophy. Literature is too multifaceted and might confuse the mind of the student, whereas philosophy goes straight to the subject matter. How does philosophy proceed in the case of Kant? With an utmost attempt at self-criticism. The end state of history, the cosmopolitan state, is not just around the corner. This is a long, arduous process in which we are involved. Kant uses terms like "infinite progress," progress without end, for that. Only toward the end can we vaguely perceive what will come. This is what Kant puts in as self-critique of his own attempt. It's arduous. You have described this on the basis of the model of nature. Hegel calls it "schlechte Unendlichkeit," "bad infinity," "poor infinity," because it does not articulate itself, it does not come to an end. The final state of cosmopolitanism is never there, it's in the process of becoming and will perhaps never be achieved. This is an important point, in my opinion, which is also contributing to the overcoming of Eurocentrism and of finding a position beyond what you call the antithesis of Eurocentrism, that is, an anti-Eurocentrism. It's precisely this moment of eternal becoming, I would say, that matters for Kant. Let me describe this a bit. Kant would say (these are my words) yes, I am Eurocentric. Yes, I am deriving from Greek history and I am nationalistic. However, I have now reached a point in history when this appears to be over, when the moment has come to turn cosmopolitan, and to turn away from nationalism. However, this won't be achieved in one moment. This will be an infinite process, and during the course of this process, we will always encounter new hindrances, new obstacles which we have to overcome. This is how I would try to rephrase Kant's attempt at overcoming Eurocentrism, namely, by describing a 
process that is infinitely going on. One last point: page fifteen, the "development of all originary faculties, or dispositions, of the human mind." This state is not just to be enjoyed socially for Kant. No, that would be Hegelian, or Marxist. This state is also to be enjoyed on the individual level. The development of all the potentialities of the individual is of course also for the benefit of the infinite process. These are some of the themes that I would like to articulate before I open the discussion.

Derrida : Thank you for what you just said. First, you noticed the question that I ask at the end of my paper: no money, there is no money. What will the state sponsor, given the military investment, and so on? I think it's a question which is a current one. Now, speaking of infinity, of this infinite process, my concern is this one. First, given our project, do we inscribe it in the horizon of a new community? Do we have to build a new universal community, or should we change the axiomatics of this cosmopolitanism. And from that point of view, I would say that, without of course wanting to be untrue to the memory of the Enlightenment, I think that today we have to rethink cosmopolitanism, given the new situation. For instance, I'm sure that all the crises that the international institutions are experiencing now, we know (I think this is true) that they have, we have to rethink the concepts, the concepts of state, of sovereignty, and so on, which are European concepts, and which are at the center of the constitution of these international institutions. These international institutions were foreseen by Kant. In a certain way, they are Kantian in spirit. So on the one hand, I would say that there is an infinite perfectibility. We have to improve. We shouldn't interrupt the work of these international institutions, the United Nations, the UNESCO, and so many others. It's something good and we have to improve them. This is an infinite process. But at the same time, it's not a continuous infinite process. We have to try and displace some concepts which are absolutely essential to these constitutions. It's not a matter of speculation, of speculative movement within the academy. What happens today in Bosnia, in Israel, and in so many places, compel the states and the nations to transform their own assumptions. And this is not simply a continuous progress, but sometimes a break, we can call it a break, in the concept of state, in the concept of internationality, in the concept of "citizen of the world," and so on and so forth. To do this, we need philosophy. That's why the question of teaching philosophy is not simply a question for teachers and pupils. It's a worldwide political question. If the citizens of all the countries are not learned, some of them, in philosophy, 
they won't understand anything to what's happening, not only in the newspaper, but in the decisions of the state, the decisions of the Security Council, and so on and so forth. Even if we think that we have to deconstruct some tradition, at the same time we have to insist that these traditions be taught, and taught more than ever. So philosophy is everywhere, philosophy is everywhere, today more than ever. And so, in order to avoid the dogmatic use or exploitation of this philosophy, teaching the discipline - that is, strengthening the people professionally - is something... is a duty. Now this question of the place for philosophy, the topos for philosophy, is a very strange question. For instance, in the German debate between Kant and Hegel, Schelling, about Humboldt - the place of philosophy within the university. As you know, some of you are, like myself, interested in this problem of the conflict of faculties. On the one hand, you have Kant, who says, well, philosophy is and should be a department, a faculty - - the lower one, under the theological, medical, and law school, but at the same time, the only place where we should be absolutely free to say whatever we want, provided that we simply speak directly and don't try to make performatives. You have this view of philosophy, occupying a circumscribed place, however privileged it may be. And then you have Schelling's (I think it's Schelling's) view. He said, well, the university is philosophical through and through. We don't need a department of philosophy; philosophy is everywhere. So is it a choice between two logics? Is it a choice? I would say no. Philosophy must be everywhere, is everywhere not only in the university, but on the radio, within the speeches of the politicians, and so on and so forth. It is everywhere. It is everywhere in the academy. There is philosophy at work in literature, in physics, and so on and so forth. Nevertheless, in addition to that, we should have a specialized training, professional training for philosophy. Otherwise, this, philosophy everywhere, could become a terrible dogmatic weapon. So that's a paradox in the topology of the discipline.

Krieger : Just very briefly. You speak more benignly than one would have anticipated of both the two kinds of philosophy, the analytic American and the continental. And certainly the problem of where philosophy is on the menu, and whether it's part of the agenda of humanistic discourses obviously rests on the relative hegemony of the analytic, Anglo-American tradition, which has held power up until now and probably for some time to come, given the nature of academic politics in the United States. 
Derrida : The linguistic hegemony cannot be dissociated from the hegemony of a type of philosophy.

Krieger : Exactly. And departmental philosophy is not only exclusionary, but the single tradition which gets traced back. But also, of course, it would exclude the rest of the humanistic discourses. I mean, it's back to the original notion that philosophy is not one of the humanistic discourses, but stands apart from them as the explanatory instrument for taking care of all the other uses of language. And to that extent, of course, there's no place around this table for most philosophy as it is taught in most parts of the United States.

Derrida : Yes, I agree. Two points, Murray. First, I said that the hegemony of the Anglo-American is all over the world, it is irreversible, something we shouldn't even try and resist. It's done. Everyone in the world will have two languages, his own plus Anglo-American. Then without trying to prevent this, we have to handle this differently. This is not only a linguistic phenomenon, because it goes hand in hand with the fact that today no theoretical work, no literary work, no philosophical work, can receive a worldwide legitimation without crossing the States, without being first legitimized in the States - we know that. That's a serious problem. It's not simply a problem of language. It is also a problem of language, but it is not simply a problem of language. And then we also know that in so many cultures, so many cultures in the world, the hegemony of the analytic philosophy is obvious. It's obvious in Asia, and it's obvious in Africa, in many parts of Africa.

Krieger : I didn't know this, by the way. You're saying something I really had no idea about. The AngloAmerican analytic is everywhere?

Derrida : In Scandinavia, even sometimes in Germany. But among the many problems which link with this phenomenon, we have the fact that analytic philosophy has little to do with the humanities.

Krieger : That's my point.

Derrida : The affinity between philosophy and literature is between continental philosophy and literature, with a few exceptions. So the problem of the humanities, of the humanistic discourse is also this problem - that analytic philosophy, if it is a serious problem, it is because there is also, despite this hegemony, some decadence.

Krieger : But also more defensiveness. 
Derrida : Yes, more defensiveness. But they don't pay any interest to arts or to literature (with some exceptions).

Birus : Well, it's in some respect a situation like in the sixteenth century, the domination of European thinking by the Latin language. All had to be translated, all relevant thoughts had to be formulated in Latin. And maybe there will be in the future some struggles like between the vernacular languages and the Latin language.

Derrida : It's unlikely to happen during our lives. You mean a new language will...?

Birus : There will be no advantage for French or German maybe, but Chinese or...

Derrida : Spanish.

Birus : Yes, but my point is the following. What could be seen as an antagonism on the linguistic level as on the philosophical level, is much more a problem of internal relationships. For instance, that English has become a universal language, that really is a danger for English as a 'natural language.' It is the domination of spoken and written English by...

Derrida : Of a certain English.

Birus : Yes, but this lingua franca. And it was one step in the Latin tradition of Latin language, to restore a true Latin against the lingua franca, that Latin spoken by the scholars and others. But on the philosophical level, there are two interesting problems. On the one hand, if you try to debate the real philosophical problems of the worldwide dominating analytical philosophy (as you, Jacques did it in Limited Inc.) you have to deal with the Vienna circle, with Wittgenstein, with Kant, and with the continental tradition as a whole. So you have to bridge the Channel and to elaborate these technically encapsulated problems. And on the other side, there are also tendencies in Anglo-American philosophy to ask for other roots and for other areas of their own philosophy. For instance, encouraged by Heidegger, Stanley Cavell's question of the philosophical impact of Thoreau.

Iser : Given the professionalism of analytic philosophy those who leave the camp are considered defectors. 
Birus : But there are very interesting outlaws, and I think they are more and more encouraged.

Derrida : I agree, I agree.

Krieger : Yes, the point is that Cavell precisely is excluded by the high church, but there is a high church. The important thing is this, that once we have conceded the tremendous priority in the universities of the sciences and of technology, we must recognize that what gives the authority and the power and a continuing place to analytic philosophy is the fact that it is what helped unlock the philosophy of science. Having worked hand in hand with some of the leading theorists in science, they're more interesting to the people who count because they keep doing their work. What they do with respect to us and the fact that they're not interested in sitting with us or in dealing with the kind of works that we read, is not going to bring them down because they have the key to the door that opens to the palace, and we don't.

Birus : But that is not a philosophical question, and I asked for philosophical questions.

Krieger : I know. But probably one other point about ours being the lingua franca: when you spoke of the disadvantage that is for us, the biggest disadvantage is one that we've all talked about, the fact that it creates a nation of persons who speak one language. Jacques said everybody around the world is going to speak two languages, his own and English. And the result is that here we are trying to discover cross-cultural relations, and we have an entire country without the languages to carry out any of them.

Birus : But that isn't true. You have Hispanics, you have Chinese - you have internal linguistic problems, I think.

Krieger : But hardly into the second generation. Pauline had to learn Chinese in a university, not at home.

Birus : In New York, advertisements are bi-lingual. Why?

Krieger : Yes, but for a first generation.

Miller : I think it's going to change a little. I think these languages will last a little longer, begin maybe to last a little longer. 
Krieger : Maybe. It's hard to know. There are so many political pressures against it.

Miller : Two things. One: I have an anecdote which certainly bears out what Jacques was saying about the imperialism of analytical philosophy. When I was in the People's Republic of China at the Chinese Academy of Social Sciences, I was with a delegation to bring news to the Chinese mainland of the new developments in many different fields - political science, business management, literature (I was the literature person), and philosophy. The philosophy person was John Searle. And we all had to give little speeches in the presence of distinguished scholars from different institutes of the Chinese Academy of Social Sciences (David Easton was the political scientist) about our fields. And Searle told them: "I have news for you. We have developed in England and the United States a definitive method in philosophy which puts an end to all previous philosophy, which is called logic and analytical philosophy, and this is now... everybody recognizes this as the predominant philosophy, and it needs to be institutionalized very rapidly here in this large country." And he said this without any irony at all, and without any sense that there might be any other possibility... That's the anecdote. The second thing is really more on the question. It seemed to me that in your preliminary remarks and even in your paper, there is a loose thread that I'd like to ask you to pick up a little more. You said in your preliminary remarks, I chose this text of Kant because of the word roman and of the explicit connection between philosophy and literature. You didn't really go on to do anything with that, and then when I listened to you talking about this role of... philosophy is everywhere, we all have to do philosophy, philosophy should be taught in the schools, and so on, and then I thought of the passage from Kant. Obviously you chose it also because it's not just literature that uses the word roman, with its connotations not only of the novel, but of the Roman.

Derrida : The Roman and the Greek.

Miller : Roman/Greek, that's right. Well, he says in the passage you quote, "however romanesque, more precisely exalted, enthusiastic." So "romanesque" and "exalted, enthusiastic" are somehow related to one another. Remember that I said I side with Proust and said it made me comfortable to know that Proust says, you want to learn about politics, read the Recherche. You now seem to be opposing philosophy and literature, and I'm interested in having you expand that relationship just 
a little bit. Obviously you don't want to be Kantian about this, but what is the relation for you between philosophy and literature if it's not the Kantian one? You see the point of my question. That is to say, it's a serious question.

Derrida : I know it, I do.

Miller : Is there any element of the literary in the kind of philosophy you're saying we all have to learn? And if so, what? Or is it simply that our concept of literature, like so many of the other concepts you named translation, all the rest of it, and therefore the very institution of literature, how we define it - is simply a philosophical one, so that not only the study of literature as a discipline, but even the writing of literature and the existence of it is simply philosophical through and through, and in that sense dominated by these philosophical concepts? You said you were not an imperialist for the philosophy department, but it sounded a little bit to me like that. And it did occur to me at some point in our discussion to remember that all of us around the table here are Doctors of Philosophy. We're called "Doctors of Philosophy" in memory, I take it, of that Humboldtian university that defined everybody who gets a graduate degree as a Doctor of Philosophy. I don't know anything about philosophy, but I have a Ph.D. I'm not a Doctor of Literature.

Behler : May I briefly interfere at this point. The systematic question remains on the table. Just a historical observation: when Kant says that he does not want to engage in a roman, he is not referring to the highest type of literature. "Roman," "novel," at that time, is no poetry at all, it's prose, "romanesque," something popular. The systematic question remains for you, Jacques, but on the historical level, Kant tries to find a middle position between strict speculation in the strong philosophical sense of the Critiques (and he doesn't do this in the essay) and fiction, mere invention. This type of philosophy has a thread, and this thread is of course very interesting.

Miller : It would be as if you would talk today about... What do you call those novels that everybody reads? Harlequin romances... romans...

Readings : The difference in French between a romance and a "roman".

Miller : Nevertheless a lot is at stake, because the passage here says that if you don't believe in the Kantian 
plan of nature [in which it's natural, absolutely natural, that there would be a development towards these international institutions - if you don't believe in that, then the only alternative to that is the Harlequin romance, that is to say, something that's not only literature, but literature of a base and popular, corrupted sort. I agree with you - that's another reason why it's important, this roman...

Behler : So there are three levels of discourse at stake. One is the hard philosophical level, which we are not discussing here. Then there is a middle level of philosophy in the sense of world wisdom, which makes use of reason in an unjustified way. And then, finally, you have fiction, mere fiction.

Derrida : Hillis, I gave up answering such an enormous question a while ago, but I'll try an elliptic answer, because it's impossible for me to say something short and clear. Just the elliptic answer would be this one perhaps: I think that the concept of literature is a philosophical concept. At least it's impossible to build this concept without some philosophy. Now at the same time, I would say that literature, some events in literature (I wouldn't speak of simply all literature), there have been some events in literature, the ones who have interested me most, which resist this philosophical concept of literature. That is, there is some invention or some events, some happenings, in what one calls "literature" which constantly undermine or displace the philosophical stabilized concept, philosophical concept of literature. So that's why I'm, as a philosopher (quote/ unquote), interested in literature - not in any literature, but in this kind of literary displacement, a writing which displaces the philosophical assumptions about literature - - now my, let's say, gesture here cannot be simple. I'm often accused, especially by some American philosophers, but also German philosophers, accused of, let's say, reducing philosophy to literature. Habermas said it publicly without shame that for me a text by Artaud or Genet and a text by Hegel is the same thing; it's homogenous. Of course I would never say such a thing, and I try to respect the limits in the functioning of what one calls a literary text and a philosophical text. But at some point, at some point, I think that since they share their belonging to a natural language, there are at work within philosophical - so-called philosophical texts, texts which are legitimized by the institution, by the academy as philosophical texts - there are in these texts some structures which could be considered literary or which have something to do with literature. Well, that's what I said the other day. For me there's no 
essence of literature, but there is a specific functioning of it. The same sentence, sometimes the same philosophical sentence - Cogito ergo sum - which in a given context is obviously a philosophical statement, can become in a different context, in a different set of statements, a literary, poetic, or anything else statement. And this, among other things, because what philosophy shares with literature is its dependence, the fact that it depends on natural language. There is no absolute formalization of philosophical language. That's why the problem of philosophy and culture, philosophy and natural language is so important. So I want to be free to respect the distinction, the rigorous distinction between philosophy and literature, and at some point to examine what in literature is philosophical. And there are a number of points where philosophy is, which can be not only interpreted as philosophemes, but which you couldn't understand without a philosophical tradition. Wordsworth - you can't read Wordsworth without knowing a lot of philosophy as such. The same with Baudelaire, with Mallarme, of course. And on the other side, there are in philosophical discourse poetic events, and there are poetic inventions in the very act of thinking philosophically. So for me it's very complicated, so I give up really on answering such a question, at least in so brief a time.

Adams : There are philosophers who have written on Wordsworth who would have been better off without their philosophy I think.

Miller : Knowing some philosophy doesn't guarantee that you'll be a good...

Adams : Huh uh. And that raised the question of what we call the philosophical concept of literature. It seems to me that one of the problems, at least in my knowledge of the profession of philosophy, is that that philosophical concept of literature has not changed much in response to literature's evasion of the concept. And that, in a nutshell, is one of the problems that we face in our relation to philosophy departments. Would you say that was true?

Derrida : Yes, I agree with you.

Adams : The philosophical concept of literature hasn't changed much since what Plato said in The Republic about the war between philosophy and literature. And I think you can see that history continue right into the analytical school of philosophy. 
Derrida : I wouldn't say it hasn't changed at all, but the changes cannot match, of course, those in literature. Hegel's concept of poetry is not Plato's concept.

Adams : If that is the case, then... I'm not going to ask you a question it's impossible for you to respond to.

Krieger : But your argument in general is that the philosophers' concept of any particular phenomenon is belied by what the phenomenon might do to exceed or violate it. You complain about their trying to have a philosophical concept of translation that would apply to all the different sorts of things that go by this word. The philosopher's concept of literature, you say, cannot stand up against the differential character of what happens, for example, in China, which might not be fittingly called "literature" at all. So what is the relation of the concept to the terms?

Derrida : I would be inclined to generalize and say the same thing for everything, but without implying that a philosophical concept is something given by Plato and remaining in place.

Krieger : Yes.

Derrida : There is a history of the philosophical concepts...

Krieger : But there's always the struggle...

Derrida : ... and philosophy tries to readjust itself to what's going on, to the movement of science, the movement of literature. So it's a historical... this adjustment is historical. What happened between Plato and Hegel's Aesthetics is a number of literary... poetic events, or theatrical... which forced Hegel to readjust his concepts. So you have to think of this historically.

Krieger : But any particular event in any particular time, you have suggested previously, can never be sustained by the concept. It must always be deconstructed.

Derrida : What I say in my polemics with Searle that according to the concept of the concept, what is a concept...

Krieger : And there is something of that sort in your concern about our using the word "translation" too easily, our using the word "literature" too easily, and the 
trouble we will get into when we get into other cultures, which may or may not even have terms for these things, which might have conceptions so radically different as not to allow them.

Derrida : That's why, Murray, although I often shout with saying the opposite, I never speak of "the philosophy" or "the philosopher" or metaphysics as a totality, as a totality. There are, within philosophy and within metaphysics, breaks, mutations, heterogeneity, and so on and so forth. So I don't think that there is "the" philosophical concept of something. There is a struggle, there is a tension. Even within a relatively stabilized concept, there is a tension at work which continues to make it work and express itself. So there is no such thing as "the philosophy," even if, for the sake of convenience sometimes, I say "philosophy." And if I were to be rigorous, I wouldn't even say "philosophy."

Birus : You would say "thinking," denken.

Krieger : Still a problem.

Derrida : Still a problem. I would try to keep a gap between philosophy and thinking. When the gap is not the same in German and in French. In German, well, since Heidegger, we oppose Philosophie und Denken. Denken cannot be reduced to metaphysics or to philosophy. What Heidegger does with the opposition between Denken and Philosophie, or Denken and danken, Denken and danken, doesn't work in French. So if I say in French "philosophie et pensée," it's something different. So I try in my own language to draw a line, an antithetical line between philosophie and pensée. But it's not the same line, although I've been inspired by Heidegger, it's not the same line as Heidegger's. Of course "philosophy and thinking" is closer to Heidegger than "philosophie et pensée." Pensée is another regime, semantic regime. But I try not to, let's say, reduce any kind of thinking or questioning to philosophy, not even to reduce philosophy to questioning, the way Heidegger, at certain points, did.

Birus : So you ask again the Heideggerian question of the relationship between philosophy and philosophical thinking as related to institutions and Denken, thinking, pensée, that is beyond or at least not defined by institutions. On the other hand, the opposition between literature and philosophy means two historically changing institutions. On the basis of these institutional limits, you can ask the questions of écriture in philosophy. 
Derrida : Well, first, when Heidegger paid attention to the philosophy as an institution, he doesn't mean all the time the academic institution. There is, of course, for him some close relationship between some sort of philosophy, especially the systematic in the narrow sense of "system," and the academy, and the German academy. But there is a broader sense of institution, and in this broad sense philosophy is associated with an institution, but not necessarily with an academic institution. Now I wouldn't say, nevertheless, that thinking as such is free from any institution, institutional roots. There is no, on the one hand, on the one side, philosophy or philosophical institutions, and on the other side, free thinking. No. I think that thinking is always also compelled by institutional norms and forms, and displaces them. And sometimes it's within an institution, within the limits of an institution that a philosophical or a thinking event may occur, then displacing the structure of the institution.

Birus : It's related to institutions, but not defined by them.

Derrida : Not exhausted, not exhausted by them. Yes.

Krieger : Could you speak a little more about one element in the paper and that you referred to in your talk? I think you said at one point in your remarks that you opened with today that Western philosophy is privileged. I thought you said that Greek or European philosophy is, in a way, privileged.

Birus : Could I add to this? You say also that philosophy is batarde in this regard.

Derrida : Yes. And my statement is a bastard from that point of view, my statement is. Because I say at the same time, you cannot use the word "philosophy" and refer to philosophy while ignoring its Greek origin. Otherwise, we would simply treat the word "philosophy" as a conventional word. So it is Greek, it has been Greek, which doesn't mean that philosophy in its history is philosophy only to the extent that it refers to the Greek origin. Even at the origin, in its Greek moment, there was already some hybridization, some grafts, at work, some differential element. So I think we could, at the same time, recall the Greek origin, the link that philosophy keeps with the Greek memory, and nevertheless welcome events which have totally displaced this Greek memory... Egyptian, Jewish, Arabic, and others. And the difficulty we have, and Heidegger 
has, in assigning an origin, whether it's Plato or whoever... This origin, even in terms of language, in terms of poetics, the way language was treated, there is no homogeneity, there is no single origin. And that's why there are events. ...

Wang : This is a very interesting discussion. I was a little confused in the beginning by your conversation, between the presenter and the chair, about the theory that philosophy is the right thing to teach, whereas literature is not for education. But then in the process, you mentioned something else. I think Pauline will agree with me that for about two thousand years, the Chinese educators wouldn't use stories or novels to teach students because they think that kind writing would confuse the students. And that's exactly what you define in the process for us. So the Chinese educators did perceive and somehow share that idea, your explanation of Kant's idea about what to teach to the students and what not to teach. In connection with this, I do have one question here. I like to use my own language and ask, do you think philosophy is an organizer of thought, or is it a generator of thoughts?

Derrida : It's a terrible question because I would like not to choose between the two and others, organizing and producing,... generating. There are structures of, let's say, speech acts which at the same time, in the same movement, produce and organize. A performative, for instance, is something which produces an event while using, organizing a given, a given material. Words exist. We have the treasure of grammar, the treasure of a lexicon. You have conventions. All this has to be organized in form. We have to shape this. So we shape, and at the same time, we generate something new. So every event is at the same time... Every new event, every newness, is at the same time shaping and producing. So I think if there is such a thing as philosophy, we could demonstrate that it is a reflection on what is, a question about what is, and the question and the reflection is what we call organizing. It shapes, it comes after the fact. There is being, and we have to think and to organize our way of apprehending it. But at the same time, the new experience, the new approach, the answer to this question is an event. It's something which produces some new thinking. So I wouldn't choose between the two. If you look at the history of philosophy, every philosopher, great philosopher, thinks or pretends, claims that he is simply reflecting, recollecting what has happened, describing... He is describing being. And he answers the question, what is being? or what is history? The answer to this question doesn't, in principle doesn't 
generate anything. It's just a reflection, a description, a constative gesture, a theoretical gesture. But at the same time, it's a praxis which produces a new structure, a new event, a new language, and it's something we do all the time, that is, organizing and generating.

Behler : Jacques, a number of participants want to comment. However, since I'm moderating I want to establish a line of thought in order to keep everything nicely together. Since we have discussed your concept or your notion of philosophy so thoroughly, we want to know whether you claim that it is not Eurocentric, that this notion of philosophy propels you beyond the antithesis Eurocentric/anti-Eurocentric. Is that a correct understanding?

Derrida : Yes, I said two things at the same time, which means that I'm not sure that there is such a thing as Europe. Or center of... Europe as a center, or center of Europe. So in fact what I had in mind is of course about Europe, about what we call "centrism" in that case.

Krieger : What could be Eurocentric without there being a Europe, out of a self-deceiving notion that there is a Europe and that we know what it is, even if we don't.

Behler : Yes, but on the other hand, if someone like Kant or Hegel or Heidegger starts out with this notion of Greekdom, of what the Greeks are, that is a clear Eurocentric line, whereas with the multiple use of origin and beginning you avoid this.

Readings : I was originally going to ask something that you've already been asked, which is what does philosophy name? And I want to ask you a question which is based on noting what seems to me an interesting and really productive irony in the relationship between the description you've given of philosophy, where you have both a functional and an institutional history of usage which is hybrid and multiple, and an attempt to hold together something like the fact that it is a Greek word. And I want to relate that to your initial point (which I think is absolutely right), which is that the world hegemony of English is not simply a matter of technological power; it also has to do with the way language works, the English language works, as opposed to the French language, the historical absence of an academy or any solely prescriptive institution concerning the language. And I wanted to sort of ask you something, which is: It seems to me that the relationship between prescription and use you've given 
in your definition of philosophy could be interestingly related to the relation between prescription and use in the development and modification of the English language, and the kind of flexibility and universalism that the English language has in relation to, shall we say, the French. And the reason for the English language's replacing it as lingua franca, which I take not to be solely historical, but also to be the question of the way in which bastardization, graft, and hybridization has proved so much more successful in English. One other footnote. In a sense I would say your notion of philosophy is in that peculiar and paradoxical sense much more English or Anglo-American than Anglo-American philosophy, which is philosophy ceasing to be philosophy because it is becoming expertise.

Derrida : Two points. I remember in my so-called debate with Searle, I tried to show him (unsuccessfully) that he was more of a continental philosopher than me, that he was more (without knowing, because I think he hasn't read Rousseau), that he is more Rousseauian than I am. So that's why I share Hendrik's point that it's not a matter of antagonism. We have to cultivate the differences within each bloc, so to speak. Another point. Perhaps what I'm doing is more translatable finally, despite a number of difficulties, translatable into the Anglo-American culture than it seems. And perhaps there is something like that which accounts for the fact that I'm so generously received in this country, because perhaps there is something which is not in my language, but in what I'm trying to say, something which fits...

Readings : I have two things to say. One is that you have to look at the very peculiar historical underpinnings. (Hillis brought in the OED: ) There's something very interesting in the way philology develops in the AngloAmerican world that is important there, and also the way literary criticism and phenomenology is split is funny. But I'm wondering whether this has something to do with the question of how you could have a non-abstract universalism, in a peculiar sense. That is to say, when I say it's more English, I'm not thinking in terms of your reception in England and America so much as in terms of the question of what kind of planetary model that would imply for a kind of contagious and bastard philosophy.

Derrida : If I had, let's say, a philosophical political stand in that respect, I would say that I'm of course attached to a universalism which wouldn't destroy the idioms. That is, how is it possible to keep the idioms - that is, the differences in language - alive without giving 
out the Enlightenment, the universalism, without, let's say, instrumentalizing the language too much. I don't think it's possible to de-technologize the language through and through. I think that techné is... even in the most poetic events, there is some techné at work, so it's impossible, I would think, impossible to oppose poetry to technology absolutely. Now, nevertheless, I would advocate a universalization which would be an experience of translation respecting the absolute singularity of the idioms. In that case, we would have organization and generation of new events - that is, the production of a new language, of new languages, a new experience of precisely grafting, hybridization, and production of new singularities. This implies another concept of cosmopolitanism, because the eighteenthcentury concept or Kantian concept of cosmopolitanism was a concept implying a secularization of language, the sort of transparency of universal language in the abstract and technical sense. Now I think the experience we make now of the new nationalisms and the attention paid to the minorities' differences call for another kind of cosmopolitanism, taking into account the idioms...

Birus : In this context, Goethe's latest use of the term Weltliteratur is of special interest. He wrote in a letter (April 24, 1831) about the translation of his last botanical writings by the French-Suiss Ferdinand Soret: "Some main passages, which my friend Soret couldn't understand in my German, I translated in my French; he translated them in his own, and so I firmly believe, they will be more generally intelligible than probably in German... These are the immediate consequences of the general world literature; the nations will take hold faster of the mutual advantages." And another example is his appreciation of the efforts of Victor Cousin and his school; with respect to them he said to Soret (October 17, 1828): "These men are on the way to effect a reconciliation of France and Germany by creating a language quite capable to facilitate the communication of ideas between both nations."And such an intermediary language is not a destruction of the idioms, but a bastardization that leads to the creation of new idioms.

Krieger : This is very brief, and really addresses this, but also it recapitulates Bill Readings' question or way of putting this. As I understand it, you're proposing (and you represent Jacques as proposing) that there is something - the word "indigenous" is not the word I want, but let me use it - within the English language that predisposes it to serve as lingua franca. What I'm thinking of is the real flowering of bastard Englishes with many varieties begins to occur, I think, in a period 
after the move toward its becoming a lingua franca is established. And I'm wondering whether we really can think of English as having peculiar potentials.

Readings : There's absolutely nothing inherent in it. It is simply a historical accident concerning the peculiar relationship of England to Enlightenment and to the question of the nation-state and the way in which linguistic policy is pursued. I view this as a historical accident which produces a bastard language. I think of America, and I think it was Jefferson (correct me if I'm wrong) who proposed discussion of the language to be adopted. They considered the plan that the language of the United States of America should be Greek, and this was seriously considered.

Miller : This was so it wouldn't be the language of the colonizer.

Readings : Yes, but also it has something to do with an idea that English gets institutionalized in a way that allows this flexibility. I am not at any point arguing that there's an inherent Geist in the English language which makes English more supple and flexible. I mean, it is also a historical bastard language in a very straightforward way which gets invaded early on.

Krieger : How pure are the language systems? And given the multiple imperialisms that we have flourishing around the world for centuries, whow could they be?

Readings : As French gets reinvented, Italian is invented...

Krieger : Yes, that's my point.

Readings : ... and English doesn't, and that's all. I mean there may well be other languages of which I am completely unaware. I'm really arguing ...

Krieger : Why is there not the multiplicity of possibilities in other nation-states that have colonial empires speaking their language?

Readings : They have these Enlightenment academies that reinvent their language on rational principles. If you have the Academie Française, which says if you say "le weekend" you're out.

Krieger : But that didn't keep French from being a lingua franca for centuries after they did that. 
Readings : In a very restricted way.

Miller : I feel like an ant crawling across the enormous expanse of this question about the relation of literature and philosophy, and if you just answer three easy questions, then my mind will be at rest. But it does follow from further discussions we had where you spoke of the performative event quality of philosophy as opposed to its simply descriptive quality. And my questions are three very specific ones. In those moments in philosophy that are literary events (you used that word), are they essential to the philosophy, or are they excrescences that could be, you know, a kind of mistake? For a minute Descartes was literary, and if we're interested in literature we find those...

Derrida : Essential, I would say.

Miller : Second question. Are they, those moments, those literary moments in philosophy, are they any longer definable by the philosophical concept of literature which...? You began by saying that the notion of literature was a philosophical concept. And the answer is...

Derrida : I would say no.

Miller : The third question, which I'm a little unclear about, is whether these events, since you're calling these literary moments "events," and therefore, since they're language, whether that leads you to say that literature as an event has something to do with a speech act, a performative use of language. The question is whether it's an accident that you speak of those literary moments in philosophy as events, and then go on later on in your discourse, in answer to the question about whether it's descriptive or constitutive, to say well, it's an event, it's a speech act, it's performative. Is theres a relationship between that aspect of philosophy and these moments which you call "literary," but which are not definable by the philosophical definition of literature, but which might be events, constitutive, something like that, and in that sense speech acts or performatives. And I'm not sure about that. I'm not trying to lead you down some kind of path.

Derrida : If we say "events," it's for many reasons. One is because they are singular, they occur just once. But it doesn't mean that they simply occur with no premises. For instance, the cogito, if you consider the cogito ergo sum as an event, this doesn't prevent you from knowing that before there is an enormous history, even in the 
history of the cogito, with Saint Augustine, and so on and so forth. There is the history and there is the event which transform the situation. Now if this event is, in some respects, a literary one, it doesn't happen just once at the moment when it is produced. There are many ways in which one can consider some literariness of the cogito. One is because it's impossible as an event without its relationship to language, to any language. Then because if you reconstitute it, then the whole structure of this event, you have to take into account the fabula, the fiction. So there is an intrinsic fictionality at work in this cogito ergo sum. Now this poeticity has not been registered or recognized at the moment when it was produced. That's why it's only a function. It's much later, perhaps in the twentieth century, that we read things differently. It's a process. It doesn't mean that Descartes was a novelist or a poet, but this can be read today as involving some literariness, some poeticity. And this is still in the process, in the collective process, and it's not the signatory who decides whether he writes literature or he writes philosophy. That's why I insist on the functionality. Perhaps it's easier today to read Descartes as a poet than it was at the time. So it's a matter of a determined community which constantly reexamines the literariness or the philosophicity. These are not essences. There are no natural philosophemes or natural works of literature. They are functions in the same languages, the same statements, grammatically and in their lexicon, can function here as everyday language, here as philosophemes, and here as poems, as poetic sentences. It depends on the context of the interpretation, of the conventions, the agreement or disagreement, and it's always a matter of discussion. Sometimes in this ongoing discussion, in this process, there are moments of great stabilization. Everyone agrees that The Critiques of Pure Reason is a major philosophical work, but it may change. Or there are some works - Rousseau, for instance, Rousseau in France - who is not considered a philosopher. His name was not on the programs of the philosophical competitions until two decades ago. So there are canonizations, canonizations, legitimations, and it's a process of assigning the functions.

Miller : A good many of our analytical philosopher colleagues would not view Kant as a philosopher. That is to say, they would say that there's no reason any longer to read Kant...

Derrida : And within a single corpus, there are works that you consider major at some point and minor at another. 
Miller : It's just as a colleague of mine is reported to have said to a student, "There's no point any longer studying Flaubert. As far as I'm concerned," she said, "all of the works of Flaubert could be burned. It would be no loss."

Krieger : It's the problem of Conrad that you were mentioning yesterday.

Iser : If I may come back for a moment to the notion of the 'universal' in philosophy. It is not culture-bound, but a universal in the normative sense of the word.

Derrida : That was a reference to Husserl, in fact.

Iser : Yes. But is that not also the plight of philosophy? A universal is not something free-floating, basically it has to fulfill a function. It is invoked when something has to be assessed, organized, or even generated. Thus it becomes entangled in a particular situation which may split a universal into those features that are relevant for the purpose concerned and those that remain eclipsed. Does it mean, then, that philosophy turns into a rescue operation, trying to restore the character of the universal as something in and of itself? This could well be a reason for the plight of philosophy as it would have to adopt a stance outside or beyond the universal for it to be determined.

Derrida : That is, everywhere there is some universality, some philosophy is...

Iser : If philosophy claims to be universal, it is always engaged in certain things which philosophy is going to do. And the moment you do any certain operations which will have repercussions on such a claim. Is philosophy all-encompassing? Or does philosophy become selfreflexive as it has to restore its claim of being universal in view of the fact that it tries to solve problems, which may not be universal by nature? Through disentangling itself from the tasks performed, it seems to elevate itself into its own subject matter. Should that be the case, then, universality stands in need of being redefined.

Krieger : That is if there's something else too: that its claim to a universal is like the sort of thing we're speaking about with respect to translation; it plays always against the awareness that its universality does not cover the particular application you want it to have. As Jacques was saying, the concept "literature" cannot contain the initiating events of the next literary work it comes upon, which is outside the concept, at least the 
one that explodes the concept... Universality is always conscious of its own inadequacy.

Iser : Well, is that the case? I would be inclined to say that in each of these instances, what claims to be a universal loses its innocence. Universality may always be on the verge of losing its innocence, because it is prone to become functional.

Derrida : I think no philosopher would ever dispute the history of philosophy as trying to constantly correct itself, adjust itself to new contents without losing its universality.

Iser : True.

Derrida : The universality that Rousseau refers to is not a given universality. He was struggling against the tide at the time. He would not deny that the philosophical works, languages, systems belong to some extent. So they were radically determined. But the philosophical project as such, the pretensions, the claim, philosophical claim, is a universal one. So it's in the name of this claim that constantly philosophy has to readjust itself to formalization in order to integrate new contents, new determinations, and so on and so forth. That's why if we keep Rousseau's example, at the same time Rousseau was claiming that phenomenology through reduction, and so on, could reach the absolute certainty beyond any doubt of a cogito again. This is absolutely universal, immediately universal, but nevertheless, historical. There is a transcendental historicity with a transcendental ideal. So at the same time you would say, well, we have an absolute ground in the cogito, in the ergo cogito, and because of this ground, which is beyond any doubt, we can build an ideal phenomenological community with an infinite historicity. In trying to comprehend, to embrace new contents, new determinations, new sciences, the progress of sciences is also infinite, and philosophy should be able to measure itself against this movement. I'm not subscribing to this. But I'm just describing the process.

Iser : Sustaining such a claim implies to deconstruct all the trappings in which universality parades. If so, then, philosophy claims toward universality, and constantly getting functionally entangled, produces stretches of wasteland as it is constantly in negotiation with itself.

Derrida : Don't think too quickly that I'm on the side of deconstruction against philosophy. We shouldn't give up this effort to universality and to try to think what's 
happening in science, in politics, and to formalize its own language, and so on and so forth. That's why deconstruction is nothing against philosophy.

Iser : I did not really intend to subject what you had said to deconstruction. Still, if you look at the current situation - especially in Germany - in which philosophy is concerned with its own history, you get another manifestation of how philosophy is always involved in and tries to cope with situations. And such an involvement is built into philosophy's claim to be universal.

Derrida : Which implies not only an attempt to integrate new scientific events - technology, political events, what happens today with the international institutions - we have to build a new role for the philosophical past.

Iser : So the universality would be the changeability of that.

Derrida : Changeability... I think for me, well, Plato is an example. I think it's something that we have to read again and again. It's a task... It's as urgent and necessary as the integration of a new role, new scientific results, and so on and so forth.

Wang : I just have one comment. I think, I always think poetry is universal. In your discussion about the importance of the universality of philosophy, I see that if I just substitute that word "philosophy" with "poetry," it sounds almost the same.

Derrida : I have no objection, except that the way it exists, it hasn't meant poetry all the time. Although I understand that today a good philosopher could write good poetry and vice versa. But I would not like to simply drop the name philosophy, although I agree with you that there is no essential difference between some poetry today and some philosophy. But I think that each time an event, be it linguistic or not, or a written event or not, each time an event produces more universality, more, let's say... opens the way, it is at the same time philosophical and poetic. Each time there is a sentence which finally calls for translation, provokes translation, becomes legible and attractive and interesting for someone in another language, in another country, then there is a something philosophical and poetical occurring at the same time.

Adams : I think, Ching-hsien, you're saying that the most particular things of poetry are the most universal. 
Wang : Are you thinking about particular things like events, histories?

Adams : The recourse to the image, I suppose, is what I'm talking about. At the expense of turning us to the vulgar here, I'm going to ask a vulgar question. What would you do about the relation of philosophy to the institution, or the departments of philosophy to the institution?

Derrida : To the institution?

Adams : To the university.

Behler : He means a particular university.

Derrida : Some facts to start with, some facts. You probably... Perhaps you know that I'm considered a professional philosopher in my own country. I teach philosophy. I'm institutionally a philosopher.

Krieger : We believe you.

Derrida : It's a professional definition in France. I'm invited and appointed here now, I've been here for seven, eight years. I almost never met a philosopher in this university. I'm probably partially responsible for that, but only partially, I would claim. Why? Well, because I think, and some students tell me that... sometimes some philosophy students come to me, and they tell me that when they name, not me, but some philosophers I'm interested in, such as Nietzsche or Hegel, the professors simply laugh at him or her and say, well, this is not philosophy. So you have an example here of the hegemony of the analytical. Now, another fact which is more recent. (Perhaps sometime I would like to discuss this with you.) I have some signs this year that something is slightly changed. It was almost the same at Yale - not exactly the same, because at Yale there were some philosophers with whom I could speak. Well, I would hope that some philosophy is taught in this university outside the Department of Philosophy, in English or in Comp. Lit. I'm sure I have nothing against the teaching of analytic philosophy. I would advocate some tolerance and some variety, more differences.

Krieger : Hazard can tell you that when he was Dean, he offered a free very fancy FTE to the Department of Philosophy if they would hire a continental philosopher.

Derrida : Changing the reference, I would say this: (I have this experience in France) I am in favor of the 
academic freedom and the autonomy of the academic field, but I know that sometimes, to change something within the corporation, the intervention of some power outside frees the situation, is necessary. Sometimes - I know that in France - the current of philosophers is simply reproducing itself constantly, constantly, and if there is no intervention from the state, from the state, or from some who are outside, it will reproduce itself for centuries without accepting anything new. And I'm sure that if you don't impose on the philosopher that they appoint someone totally foreign to their own school of thought, nothing will change for centuries.

Krieger : Do you remember at the first day or second day of our meeting this week you spoke of the violence of censorship. You spoke of Rushdie, and so on, and I said at that time that there are other kinds of censorship that are not so violent, but just as effective without killing anybody.

Derrida : I know that. I've experienced this all my life in many countries.

Krieger : You meant when you spoke of democracy, and we said, within democracy too, you believe in freedom within the university, but the university can legislate itself into a state of censorship.

Derrida : In France, for instance, there is what I call the reproduction. It is perfectly democratic, legal. There are votes, elections. Nobody's guilty of anything illegal. It's simply that they elect their disciples, and the disciples elect their own disciples, and so on and so forth, and no one comes in.

Birus : Like a bad xerox copier.

Readings : This is based on the complaints of a rather strange complaint, but an accurate one, which is that the French universities work as a medieval guild, in a way. I mean, I think there's a really interesting difference between the American university and the French university in terms of the fact that the French university has never quite had its modernity. I mean, it's never been modern in the sense that the American universities have developed. The question of reproduction for centuries: If the American philosophy department doesn't do something, it will disappear. It will disappear into local expertises...

Derrida : Because of the market too. 
Krieger : Except for the technical, the scientific people.

Readings : They will disappear away into other things.

Adams : There are moves in some philosophy departments to attach themselves to the sciences.

Yu : Cognitive sciences, computer...

Adams : ... or to the social sciences. In Washington, the Philosophy Department reports to the Dean of Social Sciences.

Krieger : And in some ways, the IDP, the interdisciplinary program that has attracted the biggest names at Irvine, is the IDP in the History and Philosophy of Science, which has a very distinguished mathematical social scientist and a number of people from the physical sciences and the philosophy of science.

Adams : Of course this problem potentially exists in every department, but it seems to me that more's at stake for the university with respect to the situation of philosophy vis-a-vis the rest of the institution than almost any other.

Derrida : I described a reproductive mechanism. It is not simply a mechanism, because the reproduction in the defensiveness is increased in situations of threat. That's why, thirty years ago in France, they were more interested: because the philosophers didn't feel threatened by some other philosophers. So it is because of the structure of the philosophical field that this reproductive defensiveness ...

Krieger : My son is an analytic philosopher. And an anecdote goes with that.

Miller : If only you'd allowed him to see the film, it would have been different...

Krieger : My anecdote is that when he was doing philosophy at UCLA, I remember it was at the very time when Rorty's Philosophy and the Mirror of Nature came out. The bookstore kept buying dozens upon dozens of copies, and they were being bought up overnight, being bought up, of course, by all the philosophy students. UCLA then was a major philosophy department in America in the analytical mode. And apparently the tightening up of the department with respect to its attitude toward its dogmas (which my son didn't see as 
dogmas), the tightening up was, in our conversations, totally evident to me with every additional copy of the Rorty book that was sold. That is, what you said about the closing of ranks and the circling the wagons was strenuously demonstrated, because the Rorty book was the first institutional awareness that something was happening, something that they couldn't control - and by one of their own, since Rorty made his early reputation as an analytic philosopher.

Behler : The time has come to conclude this last session and to thank our presenter, Jacques, and also the two organizers of these interesting sessions, Murray and Wolfgang. Thank you.

Accueil Surfaces | Table des matières | Recherche Surfaces Home Page | Table of Contents | Search

PUM | Livres | Revues | Publications électroniques | Vente et distribution 